\title{
Towards a Monumental Phenomenology: Paul Ricoeur and the Politics of Memory
}

\author{
James Ambury
}

The interplay of ideology and utopia appears as the two fundamental directions of the social imagination. The first tends toward integration, repetition, and a mirroring of the given order. The second tends to disintegration because it is eccentric. But the one cannot exist without the other. - Ricoeur, "Ideology and Utopia," 323

On the deepest level, that of symbolic mediation of action, it is through the narrative function that memory is incorporated into the formation of identity. Memory can be ideologized through the resources of the variations offered by the work of narrative configuration.

— Ricoeur, Memory, History, Forgetting, 84-85

The purpose of this paper is to explore the relationship between the two poles of the social imaginary-ideology and utopia - and the political role of memory in the work of Paul Ricoeur. I will begin by recalling Ricoeur's distinction between ideology and utopia and, in briefly recounting his arguments for their positive and perverted modalities, address the ideological role of memory. Given Ricoeur's emphasis on the importance of memory and its ideological function in societies, we find that the Ricoeurean call for a positive ideology is at the same time a call to remember, or as Ricoeur himself emphasizes, the imperative never to forget. 


\section{JAMES AMBURY}

Having thus framed the discussion, I will suggest that, while Ricoeur's phenomenology of memory attends to its inscription through language as history, his argument for the transition from individual to collective memory must be supplemented with a more robust, intersubjective, experiential account of memory that can better account for the positive ideological contribution of memory in a way that does not lead to its perversion or manipulation. This will not move us very far from Ricoeur's work on text and action, which contains within it the beginnings of the recognition of the importance of non-linguistic symbols. Suggesting an analogy between reading and the act of memorialization, I will call attention to places of memory, and specifically focus on the political monument, which spatializes memory for the purposes of engendering an intersubjective memorial experience. To conclude, I will briefly suggest the need to augment Ricoeur's work further by attending to the question of the interpretation of monuments, a question directly related to Ricoeur's insistence that democratic structures do not avoid conflict, but actually institutionalize it.

\section{Ideology, Utopia, and Memory}

While ideology is commonly understood in Marxian terms as a perverted set of values that one class imposes on another, the importance of Ricoeur's view is that it reminds us of the necessity of ideology in any society. The claim that ideology masks the interests of the working class for the benefits of the ruling class by producing an inverted image of reality rests on the presupposition that there is a point of view on action from which we can judge what is real and what is not. Echoing Kenneth Burke, Ricoeur articulates what he takes to be the problematic approach of most theories of ideology: "What these theories of ideology fail to understand is that action in its most elementary forms is already mediated and articulated by symbolic systems." "Beneath the distorting layer of representation under which there are systems of legitimacy that justify a system of authority is yet another layer of symbolic systems constitutive of action itself. There is no society without symbolism. Society is the product of symbolism, not the other way around: "Ideology is an unsurpassable phenomenon of social existence, insofar as social reality always has a symbolic constitution and incorporates interpretation, in images and representations, of the social bond itself."' 


\section{TOWARDS A MONUMENTAL PHENOMENOLOGY}

Ricoeur argues that there is an important place for ideology in society. The fundamental function of ideology is to consolidate, pattern, and provide a course of action. "IIdeology] preserves, it conserves, in the sense of making firm the human order that could be shattered by natural or historical forces, by external or internal disturbances." ${ }^{\text {'T The }}$ positive function of ideology, in this "conservative" sense, is to provide the code, or structure, by virtue of which social action takes place and in reference to which it is interpreted. The dysfunctioning of ideology, which Ricoeur calls distortion or dissimulation, occurs when ideology moves from serving as the source of authority to serving as a means of domination. In dissimulation, the legitimate use of power becomes the unsanctioned and oppressive use of force. Further, when the principle ideological schema of social interpretation cannot accommodate new or different experiences, they are marginalized or ignored in the name of social unity.

While his early work on ideology attends to the importance of founding events and stories that legitimate any social group and serve as a source of motivation for social action, it is only with his later work, specifically in Memory, History, Forgetting, that Ricoeur treats memory as an integral element of ideology. But he does so only under the heading of abuses of memory, specifically in a section concerning manipulated memory. At a very basic level, in traditional societies without a hierarchical power structure, there is only symbolically mediated action. There can be no abuse of memory, no dissimulation that legitimates a system of authority since, for all intents and purposes, there is none, at least in any Western, vertical sense. However, "It must be added straight away that this constitutive function of ideology can scarcely operate outside of its second function - the justification of a system of order or power-nor can it operate even potentially apart from the function of distortion that is grafted onto the preceding one." ${ }^{4}$ Hence, Ricoeur claims, when all is said and done, ideology revolves around power. This analysis of ideology bears an important consequence: certain memories, for the sake of legitimizing a system of authority, must be forced: "Imposed memory is armed with a history that is itself 'authorized', the official history, the history publicly learned and celebrated." ${ }^{5}$ Forced memories are ideologically necessary to guard against the forgetting of certain events and moments of our historical past that constitute the social bond. ${ }^{6}$ It is in this way that ideological memory serves its positive, integrative function. 


\section{JAMES AMBURY}

While ideology is one pole or direction of the social imagination, the other pole is utopia. Utopia may be defined as "the imaginary project of another society, of another reality, another world. Imagination is here constitutive an inventive rather than integrative manner." dialectically counterpart of ideology. At the pole of utopia, we look at reality as though from "nowhere"; we imagine different ways of using and distributing power: we imagine different structures of the family and create new possibilities for politics, economics, and religious life. As the counterpart to ideology, which, when functioning positively performs the social task of integration, utopia, in its positive function, accomplishes the task of subverting the social order for the purpose of envisioning new possibilities. Ricoeur's claim is that a society needs both ideology and utopia, as different poles of the social imaginary, to maintain a healthy tension that generates a constitutive function for the imagination and prohibits either pole from degenerating into its respective perversion.

Just as ideology finds its perverted modality in dissimulation or distortion, utopia, too, may be perverted in the modality of schizophrenia: "This pathology is rooted in the eccentric function of utopia. It develops almost as a caricature of the ambiguity of a phenomenon that oscillates between fantasy and creativity, between flight and return." Schizophrenia, as the perversion of utopia, is a kind of escapism by which praxis is eclipsed and replaced by static models of social life in the name of the demand for immediate perfection. Avoiding schizophrenia requires the admission that, no matter the clarity of social life in utopian thought, utopia is always in reference back to, and never fully disengaged from, ideology: "It is as though we have to call upon the 'healthy' function of ideology to cure the madness of utopia and as though the critique of ideologies can only be carried out by a conscience capable of regarding itself from the point of view of "nowhere."."

Given this short account of ideology and utopia, our main problem may come more clearly into focus. Ricoeur argues that ideology, in its most positive form, is a necessity to all social groups. What remains unclear, however, is the question of the maintenance of this healthy modality in terms of collective memory. Why is it, we might ask, that in his great work on memory Ricoeur only addresses the ideological function of memory in its negative function as forced and manipulated memory? Does he suspect that the memory necessary to ideology will 
inevitably become oppressive? Further, how are we to maintain memory in its positive ideological modality without allowing it to become perverted? While one may agree with Ricoeur about the importance of memory and its relationship to ideology, it is necessary to supplement his account with an analysis of collective memory that attends more fully to its intersubjective character and which addresses the question of its positive function. To develop such an account, I think we can take a cue from Ricoeur himself, who, at various moments, stresses the important relationship between memory and place.

\section{From Memory of Places to Places of Memory}

Ricoeur establishes a number of polarities in his phenomenology of memory, one of which is reflexivity/worldliness. ${ }^{10}$ One does not merely remember oneself seeing or learning, but one remembers oneself seeing or learning in a particular situation. While the pole of reflexivity accounts for the inwardness of memory, the pole of worldliness accounts for the drawing outward of memory, from the notion of corporeal memory to my body in relation to other bodies in lived space. These poles are not to be thought of as complete opposites but modalities of which different memories partake to different degrees. Take, for example, my memory of writing this paper. This memory, while it retains worldly elements, is focused mainly on my solitary exchange with texts, notes, and a computer. The memory of my presentation of this paper to a group of academic peers, while it retains its solitary elements, is much more focused on the intersubjective element of the original experience.

Ricoeur then makes a transition from corporeal memory to memory of places. When we speak of corporeal memory, we may either speak of the body as event or as habit. ${ }^{11}$ Corporeal memory is enacted in a manner similar to other habits, such as learning to drive a car. But Ricoeur argues that the body-as-habit calls upon a secondary memory, recollection, or the body-as-event, to provide precise instances of date and localization of the original memory. We here move away from the pole of reflexivity towards the pole of worldliness. While the dating or temporality of memory is no doubt important, we will here be concerned with the way in which spatiality enables the transition from individual to collective memory.

Let us then account for the transition from reflexivity to worldliness: "The transition from corporeal memory to the memory 


\section{JAMES AMBURY}

of places is assured by acts as important as orienting oneself, moving from place to place, and above all inhabiting. It is on the surface of the habitable earth that we remember having traveled and visited memorable sites." ${ }^{12}$ Ricoeur thus offers the idea of place as one way in which we can account for the transition from reflexivity to worldliness. In this transition, the focus of our memory shifts from our own corporeality to the intercorporeality of the world. I remember having been at my brother's graduation with my family or at a sporting event with my best friend. Indeed, it is these close relations, Ricoeur argues, that fill the space between individual memory, that is solely my own, and collective memory, that I share with those with whom I am not familiar: "The memory of having inhabited some house in some town or that of having traveled in some part of the world are particularly eloquent and telling. They weave together an intimate memory and one shared by those close to one."13

This in-between stage of memory, however, does not completely assist us in our project on ideology and memory. While Ricoeur is right to point out that memories of places shared with close relations account for personal identity in a way that broadens Augustine's account of memory in Book 10 of the Confessions as well as Locke's arguments about identity and diversity in An Essay Concerning Human Understanding, we are still left to question the way in which memory may maintain its ideological function for larger groups that eclipse the limits of our close relations without degenerating from serving as a justification for authority to a mask for its domination. To answer the question, I think, requires that we focus not on the memory of places but rather on places of memory.

One place of memory that can account for the worldliness of memory beyond those with whom we share close relations is the place occupied by a political monument. Instead of a place that I remember having visited with my family, and hence a referent for recollective memory - though it may be this of course - political monuments serve as places designed for the very purpose of memorialization. Any person, be it me, my brother, or someone with whom I have no prior connection, who passes through this place performs the task of memorialization. It is through places of memory that we are brought together with others for the purpose of memorializing the past.

Ricoeur calls attention to the importance of monuments throughout the course of Memory, History, Forgetting. Recounting the work of Edward Casey, he claims that there are three mnemonic modes 
that may account for the transition between reflexivity and worldliness: reminding, reminiscing, and recognizing. ${ }^{14}$ Monuments, Ricoeur claims, "function for the most part after the manner of reminders, offering in turn support for a failing memory, a struggle in the war against forgetting, even the silent plea of dead memory." ${ }^{15}$ Characterized in this way, a monument is a frozen object that initiates a mechanical association by which one thing is recalled through the experience of another, or it is an external point of reference for the purposes of recalling.

I think here that we must revise Ricoeur's treatment of monuments. These places are not merely clues that guard against forgetting but are places where we experience memory intersubjectively. More importantly: we experience memory with others whom we may know and others whom we do not know in a place expressly designed for that task. Accordingly, monuments are better grouped under the heading of reminiscing: "This is a phenomenon more strongly marked by activity than reminding; it consists in making the past live again by evoking it together with others, each helping the other to remember shared events or knowledge, the memories of one person serving as reminder for the memories of another." ${ }^{\prime 6}$ Accordingly, monuments are more than just a physical inscription or representation of researched history. They also serve as a place wherein people are brought together to intersubjectively experience memory in an active way. They are not spaces of passivity but places of work and labor. Monuments are not merely plastic objects that transmit a single memory but which call for and communicate memorial experience. We will return to the question of the communicability of memorialization below.

Monuments considered as places of memory help answer one problematic posed above-namely, how ideology can establish certain memories without oppressively forcing them. Places of memory neither force themselves upon us nor are they completely arbitrary in terms of their content and form. They evoke a memory that is acted and relived, without condemning us to slip into the compulsion to repeat. In calling us to reconstitute the social bond and attend to the ideological function of memory by sharing in the process of memorialization, they bring to us to the responsibility of maintaining a healthy degree of memory for a positive ideology.

Monuments, understood as affecting the transition from memory of places to places of memory, are one manifestation of the way in which memory may serve its positive ideological role in a nonoppressive way. A question, however, remains: if the responsibility of 


\section{JAMES AMBURY}

maintaining a positive ideological memory is ours, how do we prevent that very memory from becoming manipulated or oppressive? To reply we will attend to the construction of monuments and their relationship to historical narratives. But our answer will only lead to further hermeneutic inquiries concerning the interpretation of monuments. It is to these questions that we now turn.

\section{The Collective Experience of Memory}

In his phenomenology of reading, Ricoeur argues that reading, as a structuring activity, is the operation by which mimesis - the intersection of the worlds of reader and text- is conjoined with mimesis _ - the prefigured understanding of what human action isand mimesis $s_{2}$ the configuration or emplotment of action in a historically grounded schematized understanding of action. It is this tripartite mimetic operation with which I think we may align an intersubjective process of memorialization in terms of place. More specifically for our project here, as a text is to reading-a dialogical exchange involving a reader and a text-so a monument is to the ideological task of memorialization, executed by a multiplicity of individuals brought together by a place of memory. The monument accomplishes this bringing together, this assembling of bodies in space, through its specific architecture and design:

Between the lived space of the body and the environment and public space is intercalcated geometric space...The act of inhabiting is situated at the boundaries of lived space and geometric space. And this act of inhabiting is put in place only by an act of construction. Hence, it is architecture that brings to light the noteworthy composition that brings together geometric space and that space unfolded by our corporeal condition. ${ }^{17}$

Thus it is construction that brings bodies together for a designated purpose. The architecture of a house is different from that of a football stadium or an opera house, given the purpose for which they are constructed. The architecture of a monument is no exception. ${ }^{18}$

At the level of mimesis, Ricoeur speaks of the order of action, the "preunderstanding of what human action is, of its symbolism, its semantics, its temporality." texture of action, or acting itself, is common to both the author and 


\section{TOWARDS A MONUMENTAL PHENOMENOLOGY}

the reader of a work of fiction. It is precisely because of this shared background that the action of a text is intelligible to the reader and meaning can emerge from the text. In architecture, the background is constituted by a "dense cultural context, or web of constraints, which determines methods of construction, uses of space, symbolic systems, economic parameters, languages of architecture, etc. ${ }^{.20}$ For the architect, this background lays the foundation for the construction of a monument that can affect the task of memorialization for bodies in space, observers who themselves bring to the memorial experience a lived knowledge of human action, its basic signs, rules, and norms. This basic understanding of action on the part of the architect and the observers is what makes possible mimesis.

Mimesis $_{2}$ is the configurational aspect of Ricoeur's phenomenology of reading: "Mimesis, at this stage, signifies the production of a quasi world of action through the activity of emplotment. Far from being an effigy or a replica of action, this emplotment is its intelligible schema." 21 At this level, configuration is governed by a schematization that is structured in a tradition. Mimesis ${ }_{2}$ brings together events that are historically contingent to form a narrative whole by which they come to have a coherent meaning. Architecturally, it is at this level that an architect draws up plans for the monument and eventually constructs it. Additionally, it is here that we also situate public debate about the monument and ask about the most effective way by which to memorialize the past. ${ }^{22}$

It is at the level of emplotment in narrative form that Ricoeur places the act of construction, which gives to a certain space its purpose:

Narrative and construction bring about a similar kind of inscription, the one in the endurance of time, the other in the enduringness of materials... And narrativity impregnates the architectural act even more directly insofar as it is determined by a relationship to an established tradition wherein it takes the risk of alternating innovation and repetition. ${ }^{23}$

A monument thus serves to construct the space between bodies for the intersubjective process of memorialization within a politicohistorical context.

Finally, "mimesis ${ }_{3}$ marks the intersection of the world of the text and the world of the hearer or reader. Therefore, it is the intersection of the world unfolded by fiction and the world wherein actual action 


\section{JAMES AMBURY}

takes place." 24 This level of mimesis corresponds with what Gadamer calls application. In terms constructed space, this is the level of the actual inhabiting: "Architecture, like any other work, contains an intentional world that emerges from that which is prefigured (given) and configured (the poetic act). All works participate in this fusion of horizons." ${ }^{25}$ It is through the mediation of constructed space that we join our world with the worlds of others and engage in the shared labor maintaining ideological memory.

We now reach the crux of the ideological import of the political monument: the communicability of the experience of memorialization. Remarking on Kant's aesthetics, Ricoeur claims, "Communicability is the modality of the universal without concepts". ${ }^{26}$ What is communicated is not an objective rule, nor a particular case, but the actual play between the imagination and the understanding that never ceases in the subsumption of the experience in a concept. In viewing a monument, the experience of memorialization and interpretation occurs and reoccurs. It is this very experience that is communicable, this act of reminiscing that is shared. While no doubt pointing to specific moments in the past, monuments do not just anchor a given memory as if it were an impression in the soul: they provide the ground from which we experience the intersubjective, communicable process of memorialization. ${ }^{27}$

The objective of the artist or the architect, then, is not to hand over to us identical memories-in the sense of self-same impressions or traces - but rather to open up the possibility of analogous experience. Remarking on aesthetic experience, Ricoeur claims:

The perfect resolution of the singular problem presented to the artist is grasped in the aesthetic experience in a prereflexive, immediate manner...in the absence of objective universality proper to determinative judgment, reflecting judgment - to which aesthetic experience belongs - has, in terms of universality, only this play [between the imagination and understanding]; this is what can be shared. ${ }^{28}$

It is the very task of memorialization is what we share. Together, in our interaction with the monument, we are brought together to remember and maintain memory in its positive ideological modality.

Monuments, as we have seen, secure the intersubjective 
experience of memorialization and with it the ideological function of memory. Our final question: how is it that monuments guard against dissimulation? To answer this question, we must shift our focus to the interpretation of monuments. It is through the hermeneutic function of distanciation that we may reinterpret monuments and escape from ideology with what Ricoeur insists is not its opposite but rather its dialectical counterpart: utopia.

\section{Interpretation and the Question of Utopia}

If monuments serve ideological purposes, in the positive sense of ideology, how can they contribute to utopia? That is, given that the very purpose of a monument is to memorialize, can it simultaneously contribute to the imaginative variation of utopia by which we may escape from an ideology that has become perverted? Recalling the analogy we drew between the labor of reading and that of memorializing, consider the argument Ricoeur employs when he opens the semiological possibility of broadening our horizon of interpretation by suggesting that we extend the theory of fiction to non-linguistic symbols. Painting, for instance, presents to thought a kind of image that is public because it is essentially external. Against the Platonic claim that the painter composes a shadow-image that makes the mind deviate from reality, Ricoeur claims, "it is precisely the externalization of thought in external marks which has encouraged the creation of images which not only are shadows or similarities, but also offer new models for perceiving". ${ }^{29}$ The external image, because it is ambiguous, invites and motivates interpretation and has the ability to transform what we in ordinary language call reality. ${ }^{30}$

Like a text, a monument acquires a certain semantic autonomy because it is cut off in three ways: from the intention of its author or builder, from the capacity of its first audience to receive it, and from the socio-cultural conditions of its genesis. ${ }^{31}$ With every new observer, there is the possibility of new interpretation. This is one hallmark of Ricoeurean hermeneutics: given that there is always distanciation, there will always be interpretation. By way of the externalization of images in art we may come to understand the importance of the spatialization of memory. The semantic autonomy of monuments, hermeneutically speaking, prevents, always already, a single narrative from dominating others. It avoids an unhealthy forgetting: 


\section{JAMES AMBURY}

The resource of narrative then becomes a trap, when higher powers take over this emplotment and impose a canonical narrative by means of intimidation or seduction, fear or flattery. A devious form of forgetting is at work here, resulting from stripping the social actors of their original powers to recount their actions themselves. ${ }^{32}$

Because they are hermeneutically open to mimesis, monuments themselves may prevent the perversion of dissimulation. Given our argument that monuments engender the experience of memorialization as such and not just the retention of individual memories, the process is inherently open to intersubjective reinterpretation.

The following point, however, is stronger. Consider Ricoeur's striking claim in Oneself As Another.

Democracy is not a political system without conflicts but a system in which conflicts are open and negotiable in accordance with recognized rules of arbitration. In a society that is ever more complex, conflicts will not diminish in number and in seriousness but will multiply and deepen... [democracy] is the system that accepts its contradictions to the point of institutionalizing conflict. ${ }^{33}$

By extension, what we could call a democratic monument, in its very construction, maintains a positive ideology but simultaneously engenders reinterpretation - indeed, multiple interpretations that will conflict — and utopian thought. In serving the conservative ideological purpose and memorializing the past, democratic monuments are not just open to interpretation because of the hermeneutic reality of semantic autonomy. Architecturally and phenomenologically, democratic monuments are those that are constructed in such a way that the observer is acutely aware of his or her participation in the process of memorialization that opens up its narrative to the movement of mimesis. They leave open the distanciative possibility of utopia, and guard against dissimulation by giving to observers the power to tell the memorial narrative for themselves. ${ }^{34}$ Observers come to understand their role in constituting the predominant ideology while simultaneously reinterpreting it to prevent its descent into the perversion of dissimulation. Such monuments admit of the greatest degree of polysemy without completely abandoning their ideological, memorial function. 


\section{TOWARDS A MONUMENTAL PHENOMENOLOGY}

Beginning with Ricoeur's analysis of ideological memory and introducing the question of its maintenance without perversion, we found that monuments, as places of memory, serve to guard against forgetting not just as reminders but as symbols that motivate an intersubjective experience of memorialization understood as reminiscing. Having analyzed monuments in terms Ricoeur's phenomenology of fiction, we said that, while monuments contribute to the ideological function of memory without manipulating memory, we nevertheless bear the responsibility for constructing monuments that are not merely interpretable but that engender interpretation. This type of monument we called democratic. A monument is democratic in the sense that, while retaining the ideological-memorial ground necessary for the constitution of any social action, it preserves the function of the social imaginary by giving observers the power to narrate for themselves and, when necessary, escape ideology through recourse to utopian thought. In his work on ideology, utopia, and memory, it is perhaps towards a monumental phenomenology that Ricoeur is pointing us: what remains to be done now is a detailed phenomenological analysis of the architecture of democratic monuments.

SUNY Stony Brook

\section{Notes}

${ }^{1}$ Paul Ricoeur, "Ideology and Utopia" in From Text To Action, trans. Kathleen Blamey and John B. Thompson (Evanston: Northwestern University Press, 1991), 327. Ricoeur is here agreeing with Clifford Gertz's theory of symbolic action in The Interpretation of Cultures (New York: Basic Books, 1973) which itself argues that we adopt Kenneth Burke's theory in Philosophy of Literary Forms: Studies in Symbolic Action (Berkeley: University of California Press, 1974). For Ricoeur, action is always symbolically mediated, not merely in terms of its historical embeddedness, but in its very structure. We will develop this point further in our discussion of Ricoeur's analysis of mimesis.

${ }^{2}$ Paul Ricoeur, "Science and Ideology" in From Text To Action, 255.

${ }^{3}$ Ricoeur, "Ideology and Utopia, 318.

${ }^{4}$ Paul Ricoeur, Memory, History, Forgetting, trans. Kathleen Blamey and David Pellauer (Chicago: University of Chicago Press, 2004), 83. A useful summary of this work as a whole is Charles Reagan, "Reflections on Paul Ricoeur's Memory, History, Forgetting” Philosophy Today 49, no. 3 (2005): 309-316. 


\section{JAMES AMBURY}

${ }^{5}$ Ricoeur, Memory, History, Forgetting, 85.

${ }^{6}$ Ricoeur characterizes recollection, or the anamnesis of the Greeks, as guarding against Lethe, the river of oblivion (Memory, History, Forgetting, 27). Hence the search for a particular memory is battle waged against forgetfulness. Ricoeur will later align the duty to remember with the duty to do justice to an other than self (Memory, History, Forgetting, 88-89).

${ }^{7}$ Ricoeur, "Ideology and Utopia," 318.

${ }^{8}$ Ricoeur, Ideology and Utopia," 318.

${ }^{9}$ Ricoeur, "Ideology and Utopia," 324. Curiously, Ricoeur has very little to say about utopia and its relationship to memory. While our final section will just begin to address this issue, certain questions still linger: to what extent must memory be abolished for the purposes of performing the distanciative function of utopia? If utopia calls for not just a passive but a willed forgetting, similar to what Nietzsche calls for in his second Untimely Meditation, how do we avoid the danger that Ricoeur himself points out, i.e., of forced forgetting? What role might forgiveness, which Ricoeur discusses in the epilogue to Memory, History, Forgetting, play in utopia?

44.

${ }^{10}$ See his argument for this polarity in Memory, History, Forgetting, 36-

${ }^{11}$ Ricoeur is here evoking yet another pair of poles for which he argues, the poles of habit/memory, and follows the famous argument that Henri Bergson gives in his Matter and Memory. One may, for instance, learn a certain lesson by repetition. This is habit. The memory of the learning itself, or the event of sitting down to memorize, is memory or recollection. For Ricoeur's initial treatment of Bergson, to whom he will consistently return, see Memory, History, Forgetting 23-30. Bergson's argument for the two types of memory is found in Matter and Memory, trans. N.M. Paul and W.S. Palmer (New York: Zone Books, 1991), especially 81-88.

${ }^{12}$ Ricoeur, Memory, History, Forgetting, 41.

${ }^{13}$ Ricoeur, Memory, History, Forgetting, 148. It is with this transition that Ricoeur ends his phenomenology of memory, Memory, History, Forgetting,131-132. It is worth noting here that Ricoeur gives considerable treatment to Maurice Halbwachs' The External Gaze, trans. Francis J Ditter and Vida Yazdi Ditter (New York: Harper Colophon, 1950, reprinted 1980), which argues that all memory is collective. We do not derive collective memory from individual memory, but the case is rather the other way around. It is ultimately this derivation about which Ricoeur has reservations, and substitutes our close relations as a mediator between individual and collective memory. See Memory, History, Forgetting, 120-124.

${ }^{14}$ Edward Casey, Remembering: A Phenomenological Study (Bloomington: Indiana University Press, 1987).

${ }^{15}$ Ricoeur, Memory, History, Forgetting, 41.

${ }^{16}$ Ricoeur, Memory, History, Forgetting, 38. 


\section{TOWARDS A MONUMENTAL PHENOMENOLOGY}

${ }^{17}$ Ricoeur, Memory, History, Forgetting, 150.

${ }^{18}$ Many of the remarks that follow are drawn from Graham Livesey's short but very informative essay, "The Role of Figure in Metaphor, Narrative, and Architecture" ("Architecture") in Paul Ricoeur and Narrative: Context and Contestation, ed. Morny Joy (Calgary: University of Calgary Press, 1997), 2534.

${ }^{19}$ Paul Ricoeur, "Mimesis and Representation" in A Ricoeur Reader: Reflection and Imagination, ed. Mario J Valdes (Toronto: Toronto University Press, 1991).

${ }^{20}$ Livesey, "Architecture," 27.

${ }^{21}$ Ricoeur, "Mimesis and Representation," 143.

${ }^{22}$ The import of this debate, while not the subject of our project here, cannot be overstated. Ricoeur discusses the importance of the mourning process that social groups must pass through if they are to transcend traumatic memories in Memory, History, Forgetting, 69-80. Social groups must 'work through' these memories symbolically if they are to avoid the danger of Freudian melancholia, marked by the compulsion to repeat without healing. This repetition, Ricoeur argues, amounts to a kind of forgetting (Memory, History, Forgetting, 444-448). Mourning is distinguished form melancholia in that, though they are both painful, mourning is followed by the individual or community freeing itself from the traumatic memory. It is in this sense that, in the United States, we are only now, symbolically, coming to terms with the importance of the civil rights movement with the creation of the Martin Luther King Memorial on the mall in Washington, DC, and that, given the stagnated rebuilding process at ground zero in New York City's Lower Manhattan, we are still entrenched in the melancholia of September 11.

${ }^{23}$ Ricoeur, Memory, History, Forgetting, 150.

${ }^{24}$ Ricoeur, "Mimesis and Representation," 148.

${ }^{25}$ Livesey, "Architecture", 28.

${ }^{26}$ Jean-Marie Brohm and Magali Uhl, "Arts, Language, and Hermeneutic Aesthetics: An Interview with Paul Ricoeur" trans. R.D. Sweeney, available online at www.philagora.net/philo-fac/ricoeur.htm. Accessed September 15, 2006.

${ }^{27}$ The question of the spatiality of memory, that is, where memories are preserved, has plagued Western thought since Plato. This is one reason why my emphasis remains on the experience of memorialization as such. Ricoeur consistently returns to the problem throughout Memory, History, Forgetting, and his initial treatment of Plato and Aristotle (Memory, History, Forgetting7-21) is useful for diagnosing its conceptual origin. Ricoeur proceeds to cite Bergson as one of the few philosophers brave enough to challenge the very composition of the problem in terms of space. Memory, for Bergson, is not a thing preserved anywhere; it is preserved in itself. A very useful explication of this position is Gilles Deleuze's Bergsonism, trans. Hugh Tomlinson and 


\section{JAMES AMBURY}

Barbara Habberjam (Zone Books, 1988), Chapter 3, "Memory as Virtual Coexistence", especially 54-62. Nevertheless, Ricoeur points out the trouble that even Bergson has with the spatiality of memory; see Memory, History, Forgetting, 434-435.

${ }^{28}$ Paul Ricoeur, Critique and Conviction, trans. Francois Azouvi and Marc B. De Launay (NY: Columbia University Press, 1998), 180.

${ }^{29}$ Paul Ricoeur, "The Function of Fiction in Shaping Reality" in $A$ Ricoeur Reader, op cit.

${ }^{30}$ Ricoeur's remarks on the ambiguity and thus interpretive potentiality of painting are echoed by Merleau-Ponty in his essay "Cezanne's Doubt" reprinted in The Merleau-Ponty Aesthetics Reader, ed. Galen A. Johnson (IL: Northwestern University Press, 1993) 3-14. For an elaboration on Ricoeur's views on painting, see Paul Kidder, "Interpretation and the Speechless Image" and Mario Valdes, "Paul Ricoeur's Hermeneutics of Painting" in Between Suspicion and Sympatby: Paul Ricoeur's Unstable Equilibrium, ed. Andrzej Wiercinski (Toronto: Hermeneutic Press, 2003).

${ }^{31}$ I here follow Ricoeur's discussion of semantic autonomy in "Mimesis and Representation", 143-148.

${ }^{32}$ Ricoeur, Memory, History, Forgetting, 448.

${ }^{33}$ Paul Ricoeur, Oneself As Another, trans. Kathleen Blamey (Chicago: University of Chicago Press, 1992), 258-260.

${ }^{34}$ In arguing for the intersubjective responsibility that characterizes both memory and forgetting, Ricoeur emphasizes the power to narrate for oneself. The motto of the Enlightenment, he claims, sapere aude (move out of the state of tutelage) is best rewritten as: dare to give an account of yourself (Memory, History, Forgetting, 449). 